\title{
Thrips (Thysanoptera) associated with two genetically modified types of linseed (Linum usitatissimum $\mathbf{L}$.)
}

\author{
Michal Hurej $^{1} \cdot$ Halina Kucharczyk ${ }^{2} \cdot$ Jacek Piotr Twardowski $^{1} \cdot$ Andrzej Kotecki $^{3}$
}

Received: 8 April 2016/Accepted: 5 October 2016/Published online: 18 October 2016

(c) The Author(s) 2016. This article is published with open access at Springerlink.com

\begin{abstract}
The aim of this study was to determine thrips abundance, species composition and seasonal dynamics on two genetically modified types of linseed, i.e., overproducing flavonoids, overproducing glycoside derivatives of phenylpropanoids and the respective non-modified, control plants with concentrations of phenylpropanoids typical for this variety. The experiment was conducted near Wrocław, Poland, in 2011-2013. For the determination of thrips species composition, 10 plants were collected from plots when linseed plants were at the full blooming stage. A sweep net was also used to study thrips on flax. In the three years of the study, 33 species and 2 genera of Thysanoptera were identified on oil flax plants. Irrespective of the type of linseed used, Thrips angusticeps was the dominant species. In the three years of the study, the lower numbers of thrips occurred on the genetically modified types of flax, i.e., the ones overproducing flavonoids or overproducing glycoside derivatives of phenylpropanoids than on the non-transformed plants. Fewer species of Thysanoptera were identified on oil flax overproducing flavonoids in comparison with the control plants.
\end{abstract}

Jacek Piotr Twardowski

jacek.twardowski@up.wroc.pl

1 Department of Plant Protection, Wrocław University of Environmental and Life Sciences, Grunwaldzki 24a, 50-363 Wrocław, Poland

2 Department of Zoology, Maria Curie-Skłodowska University in Lublin, Akademicka 19, 20-033 Lublin, Poland

3 Department of Crop Production, Wrocław University of Environmental and Life Sciences, Grunwaldzki 24a, 50-363 Wrocław, Poland
Keywords Genetically modified plants · Oil flax · Thysanoptera $\cdot$ Species composition - Abundance . Phenylpropanoids effect

\section{Introduction}

Linseed (flax, Linum usitatissimum L.), one of the oldest cultivated crops, continues to be widely grown for oil, fiber and food [40]. In the 2014, the global world linseed production area harvested was 2,600,554 ha. The important cultivation areas of this crop were located in Canada, the traditional leader of flax cultivation $(620,800 \mathrm{ha})$, followed by Kazakhstan (446,000 ha) and Russian Federation (441,475 ha). The largest areas of linseed production within the European Union were located in the UK $(15,000$ ha), France (10,993 ha), Belgium (10,000 ha) and Spain (9,500 ha). Other smaller producers were Sweden (6560 ha), Germany (4200 ha) and Poland (2386 ha) [11]. A decrease in linseed area harvested is evident in Western European countries since the year 2000. The possible reason of such situation can be removal of fiber flax and linseed subsidies that growers had been receiving to grow this crop. Basically, linseed products might be used in different branches of industry. Flax plant utilization for food, feed and fiber, as well as processing of flaxseed has been recently thoroughly reviewed [49]. Numerous prospective applications of linseed are pointed out in the review of Zuk et al. [62]. Hence, considering such promising and wide spectrum of linseed applications, there is hope that this crop will again become popular and highly prized in the nearest future.

The recognized beneficial properties of linseed are mainly associated with its oil, but a great amount of bioactive phytochemicals remains in the seedcake (the leftovers of the flax seeds after oil extraction). Flax seed 
cake contains phenolic acids, flavonoids and other phenylpropanoids that are known to show a wide range of biological activities and thus have a beneficial influence on human health [27]. The valuable effects of these compounds are mainly due to their antioxidant properties. The beneficial properties of linseed products could clearly be enhanced if the secondary metabolite accumulation in the plant organs could be increased. To increase the level of flavonoids and other phenylpropanoids and their glycoside derivatives, two genetically modified linseed types were generated [7, 61].

Plant phenylpropanoids are a very broad group of biochemical compounds which form secondary metabolites in enzymatic biosynthesis. They include flavonoids, phenolic acids, phenols, lignans and tannins [36]. Flavonoids are a group of secondary plant metabolites important for plant growth and development. They defend plants against various biotic and abiotic stressors, including pathogens and insect pests. Flavonoids can have a negative effect on nonadapted insects or may reduce the nutritive value of their food. They may behave as antifeedants, as digestibility reducers and as toxins [47, 48, 54, 57]. Plants currently bred for increased levels of phenolics might well influence different aspects of insect-plant interactions but as yet we do not have enough data available to evaluate what these effects might be. Studies on these interactions are needed if we are to have a better understanding of how increasing the expression of a group of organic compound-like flavonoids in plants could influence insect ecology.

A few species of thrips are pests of flax and by feeding on this plant they cause damage to both fiber and oil flax. The adult and larvae of Thrips linarius and T. angusticeps are mentioned as main pests of flax in Europe $[4,14,8,16,17,59,60]$. Besides the above-mentioned species T. tabaci and the predatory Aeolothrips intermedius breed on flax [59]. Many other herbivorous species of thrips have been identified in this crop [12, 14, 59]. Most of them are relatively rare and are not known to cause noticeable crop damage. T. linarius is a monophagous insect which feeds primarily on flax [8, 14, 59]. In most areas of Europe, this species produces one complete generation [4, 14]. In Romania, a partial second generation has been observed, and in Poland two complete generations $[6,60]$. $T$. angusticeps is a polyphagous, widespread and common species in Europe. It prefers flax but feeds on many crops, like sugar beet, onion, peas, narrow-leafed lupin, broad bean, winter wheat and winter rye $[10,21,41,44,51,52,58]$. T. angusticeps has two generations per year in Europe [8, 59]. According to research by Franssen and Huisman [13], in the Netherlands the first is formed by wintering brachypterous specimens feeding and breeding on flax seedlings, the second by the macropterous ones feeding on flowers and fruits. The third herbivorous species which can breed on flax, T. tabaci is a worldwide pest of agricultural and vegetable crops. It causes damage to cucumber [43], onion [39], leek [31], cabbage [25, 34, 42], pea [41], potato and tomato [15]. Besides the direct damage, adults of this pest can transmit tomato spotted wild virus (TSWV) [46]. The number of annual generations of T. tabaci depends on climatic conditions. In cold areas, 2-3 generations may be produced. In warmer regions, the number of annual generations is about 6-8 [15]. In the Netherlands, oats thrips (Stenothrips graminum) were very frequently collected on flax plants as well [14].

The aim of this study was to determine thrips abundance, species composition and seasonal dynamics on two genetically modified types of linseed, i.e., overproducing flavonoids and overproducing glycoside derivatives of phenylpropanoids. It was expected that overproduction of the secondary metabolites can influence the thrips populations.

\section{Materials and methods}

Two genetically modified types of Linum usitatissimum (cv. Linola) were used: type A-overproducing flavonoids (in tables and figures marked as A) [61], type B-overproducing glycoside derivatives of phenylpropanoids (B) [7] and the respective non-modified, control plants cv. Linola containing concentrations typical for this variety of phenylpropanoids (type C) (C). The experiment was conducted at the Experimental Research Station in Pawłowice, near Wrocław, Lower Silesia, Poland $\left(51^{\circ} 1737^{\prime} \mathrm{N}\right.$, $\left.17^{\circ} 1176^{\prime} \mathrm{E}\right)$ during three growing seasons (2011-2013). Plants were grown on $15 \mathrm{~m}^{2}$ plots $(10 \mathrm{~m} \times 1.5 \mathrm{~m})$ of sandy soil. The $0.3 \mathrm{~m}$ wide space between the experimental plots was maintained mechanically as bare soil, and the plots were weeded regularly. The experiment was designed as a split-plot with four replicates for each genetically modified type and for control cv. Linola of L. usitatissimum. Six hundred seeds per $1 \mathrm{~m}^{2}$ were sown in each treatment.

Two different methods of thrips collection were used. For the determination of thrips species composition, 10 plants were collected from the central part of each plot (40 plants for treatment) when oil flax plants were at the full blooming stage (BBCH 65). In the laboratory, plants were shaken over a sheet of white paper. Larvae and adults were counted, preserved in $75 \%$ ethyl alcohol and then identified. Every second week thrips were also collected by a sweep net (38 cm in diameter). A sample consisted of 10 $180^{\circ}$ sweeps taken in the middle of each plot on each sampling date. Samples were placed individually into cardboard containers with a paper towel saturated with 
$95 \%$ ethyl acetate. Samples were taken to the laboratory, where insects were hand separated from plant material and placed in vials containing $75 \%$ ethyl alcohol. Samples were later sorted, and specimens were counted and identified.

The sex ratio is the percentage of females in a population. It was calculated using the standard formula:

$\mathrm{Sr}=f:(m+f) \times 100$,

where $S r$-sex ratio, $f$-number of females, $m$-number of males [55].

The numbers of thrips found using three different sampling methods in different treatments of the experiment were compared using the analysis of variance (ANOVA) followed by Tukey's HSD (post hoc). Statistical significance was evaluated at $P \leq 0.05$. For statistical analysis, Statistica software, version $12 \mathrm{PL}$, was chosen (StatSoft Inc. Poland [50]).

\section{Results and discussion}

\section{Abundance and species composition: sweep net collection}

In 2011, 6 collections by a sweep net were done. A total of 646 thrips belonging to 18 species were identified in the collected material from all the treatments (Table 1). A significantly lower number of thrips was found in type B oil flax (overproducing glycoside derivatives of phenylpropanoids) (72 individuals) in comparison with non-modified plants (367) $(F=4.35, \quad d f=2$, $P=0.0176)$. The lowest number of species was also determined in type B (6), while in type A (12) and in control plants (17). In each treatment, the most numerous species were Aeolothrips intermedius and Thrips angusticeps. The first species made up from $40.6 \%$ (type A) to $66.7 \%$ (B) of all identified thrips and was especially abundant in the non-modified cultivar. The second species made up from $13.9 \%$ (B) to $26.6 \%$ (A) of all collected thrips.

In 2012, in 6 sweep net collections a total of 6203 thrips belonging to 23 species were found (Table 2). This was the highest number of determined Thysanoptera during the three years of the study. No significant differences in the number of recorded insects were found between treatments $(F=0.15, d f=2, P=0.855)$. From 15 (type A, type C) to 19 (type B), species were identified. In each treatment, the most numerous species was $T$. angusticeps, making up from $66.9 \%$ (type B, type C) to $71 \%$ (type A) of all collected thrips. Two additional species were also abundant in all the studied treatments, i.e., A. intermedius and $T$. tabaci. The percentage of A. intermedius in the total number of thrips recorded in each treatment was similar and fluctuated from 14 to $17.7 \%$. T. tabaci made up from 13 to $16 \%$ of all Thysanoptera. Other identified species occurred in much lower numbers in the collected material and not in each treatment.

In 2013, as in previous years, 6 collections by a sweep net were done. A total of 4495 thrips belonging to 22 species and 2 genera were identified in the collected material from all the treatments (Table 3). This year, significantly more Thysanoptera were found on control plants (1817) in comparison with type A plants (1192) $(F=6.4$, $d f=2, P=0.0029)$. Irrespective of the number of collected insects in each treatment, the number of identified species was almost the same (16 or 17). As in the previous year, T. angusticeps was the dominant species in each treatment, making up about half of all identified Thysanoptera (from 44.9 to $56 \%$ ). The second most numerous species was A. intermedius, comprising $24 \%$ of insects from all treatments (A-16.5\%, B-20.8\%, C-4\%). The abundance of this species was almost three times as high on plots of non-modified plants as on type A. T. tabaci was also numerous and occurred in similar numbers in the three studied treatments.

\section{Abundance and species composition: shaking method}

Much fewer Thysanoptera were collected by shaking plants over a sheet of white paper than by using a sweep net. In the three years of our study, no significant differences in numbers of thrips were found between treatments. In 2011, only 40 thrips belonging to 6 species were collected by this method from all the treatments of plants which were at the full blooming stage (BBCH 65) (Table 4). Only 3 species were identified on type A, 6 species on type B and 4 on control plants. In each treatment, $T$. tabaci was the dominant species, making up about $50 \%$ of all identified Thysanoptera. The second most numerous species was $T$. angusticeps, comprising $25 \%$ of all insects.

In 2012, a total of 127 thrips were found in the collected material. Among them 5 species were identified, 3 or 4 in each treatment (Table 4). Insects occurred both in the adult and the larval stages. This year, T. angusticeps was the distinct dominant, and made up $78.3 \%$ of all found Thysanoptera on type A oil flax plants, $69.5 \%$ on type B and $75.6 \%$ on type $\mathrm{C}$ plants. T. tabaci was also abundant: $17.4 \%$ in type A, $22 \%$ in type B and $13.6 \%$ in control plants.

In 2013, a total of 88 thrips were found using the shaking method (Table 4). In the collected material, only 2 or 3 species were identified in the treatment. As in the previous year, T. angusticeps was the distinct dominant and constituted from $82.4 \%$ (type B) to $93.1 \%$ (type A) of all 
Table 1 Species composition of thrips collected by sweep net in 2011

\begin{tabular}{|c|c|c|c|c|c|c|c|c|}
\hline \multirow[t]{2}{*}{ Species } & \multicolumn{2}{|l|}{$\mathrm{A}^{\mathrm{a}}$} & \multicolumn{2}{|l|}{$\mathrm{B}$} & \multicolumn{2}{|l|}{$\mathrm{C}$} & \multirow[t]{2}{*}{ Total } & \multirow[t]{2}{*}{$\%$} \\
\hline & $N^{\mathrm{b}}$ & $\%$ & $N$ & $\%$ & $N$ & $\%$ & & \\
\hline Aeolothrips intermedius Bagnall, 1934 & 84 & 40.6 & 48 & 66.7 & 221 & 60.2 & 353 & 54.6 \\
\hline Thrips angusticeps Uzel, 1895 & 55 & 26.6 & 10 & 13.9 & 72 & 19.6 & 137 & 21.2 \\
\hline Thrips tabaci Lindeman, 1889 & 30 & 14.5 & 2 & 2.8 & 12 & 3.3 & 44 & 6.8 \\
\hline Frankliniella intonsa (Trybom, 1895) & 9 & 4.3 & 2 & 2.8 & 19 & 5.2 & 30 & 4.6 \\
\hline Frankliniella tenuicornis Uzel, 1895 & 12 & 5.8 & 6 & 8.3 & 8 & 2.1 & 26 & 4.0 \\
\hline Chirothrips manicatus Haliday, 1836 & 3 & 1.4 & & & 13 & 3.5 & 16 & 2.5 \\
\hline Limothrips denticornis Haliday, 1836 & 6 & 2.9 & 4 & 5.6 & 6 & 1.6 & 16 & 2.5 \\
\hline Haplothrips aculeatus Fabricius, 1803 & 2 & 1.0 & & & 4 & 1.1 & 6 & 0.9 \\
\hline Thrips atratus Haliday, 1836 & 2 & 1.0 & & & 3 & 0.8 & 5 & 0.8 \\
\hline Anaphothrips obscurus (Muller, 1776) & 2 & 1.0 & & & & & 2 & 0.3 \\
\hline Haplothrips setiger Priesner, 1921 & 1 & 0.5 & & & 1 & 0.3 & 2 & 0.3 \\
\hline Limothrips cerealium Haliday, 1836 & 1 & 0.5 & & & 1 & 0.3 & 2 & 0.3 \\
\hline Thrips major Uzel, 1895 & & & & & 2 & 0.5 & 2 & 0.3 \\
\hline Chirothrips hamatus Trybom, 1895 & & & & & 1 & 0.3 & 1 & 0.2 \\
\hline Odontothrips loti (Haliday, 1852) & & & & & 1 & 0.3 & 1 & 0.2 \\
\hline Thrips fuscipennis Haliday, 1836 & & & & & 1 & 0.3 & 1 & 0.2 \\
\hline Thrips physapus Linnaeus, 1758 & & & & & 1 & 0.3 & 1 & 0.2 \\
\hline Thrips trehernei Priesner, 1927 & & & & & 1 & 0.3 & 1 & 0.2 \\
\hline Total & $207 a b^{c}$ & 100 & $72 b$ & 100 & $367 a$ & 100 & 646 & 100 \\
\hline Number of species & 12 & & 6 & & 17 & & 18 & \\
\hline
\end{tabular}

Superscript 'a' indicates type of linseed: A-linseed overproducing flavonoids, B-linseed overproducing glycoside derivatives of phenylpropanoids, $\mathrm{C}$-non-modified linseed, superscript ' $\mathrm{b}$ ' indicates number of thrips and superscript 'c' indicates significant differences in total numbers of thrips

Different small letters next to total numbers of thrips indicate significant differences between the treatments identified Thysanoptera. Single specimens of $T$. tabaci were also recorded in samples from each treatment.

In the three years of the study, 33 species and 2 genera of Thysanoptera occurring on oil flax were collected using two methods of collection, sweep net and shaking plants over a sheet of white paper. Three of them were the most numerous: $T$. angusticeps, $T$. tabaci and A. intermedius. In terms of the feeding group, two first mentioned species are phytophagous, and A. intermedius is zoophagous. $T$. angusticeps was the dominant species irrespective of the type of oil flax used. It prefers flax but feeds on many other crops, like sugar beet, onion, peas, narrow-leafed lupin, broad bean, winter wheat and winter rye [10, 21, 41, 44, 51, 52, 58]. T. tabaci, which was the second important phytophagous species on oil flax, is an important pest of onion, other onion relatives, and several crops in most parts of the world [15, 25, 31, 34, 39, 41-43]. Thrips linarius, mentioned in the literature as a main pest of flax in Europe [4, 8, 16, 17, 59, 60], was not identified in our trials. This species is a monophagous insect which feeds primarily on flax. Flax plants were not grown for many years in the region of our trials. Therefore, we suppose that the prolonged absence of the host plant in this area was the main reason for the lack of $T$. linarius in the collected entomological material. This species was the only pest observed by Kucharczyk [28] on flax crops in the Lublin Upland (southeastern Poland).

The zoophagous A. intermedius, commonly occurring in our trials, was reported as a predator of 44 species of the order Thysanoptera [45]. Predatory larvae and adults feed mainly on the larvae of other thrips, on aphids and also on the larvae and eggs of other insects. Moreover, adults of $A$. intermedius can also feed on pollen [5]. In Poland, the presence of this species has been recorded in the flowers of many plant species, including herbs [29]. In the same location, it was found as an abundant species on Andean lupin, narrow-leafed lupin and Triticum durum [20-22]. In the sweep net collection, this species was always much more numerous in samples from control plants than from type A plants.

\section{Sex ratio of the most numerous species}

Taking into account the three years of our study and the three types of oil flax, the calculated mean sex ratio of Thrips angusticeps collected by the sweep net method was $86.3 \%$ and ranged from 74.2 to $96.4 \%$ (Table 5). Similar values of this ratio were calculated for each treatment. In winter rye, the sex ratio of $T$. angusticeps reached $96.8 \%$ [51]. 
Table 2 Species composition of thrips collected by sweep net in 2012

\begin{tabular}{|c|c|c|c|c|c|c|c|c|}
\hline \multirow[t]{2}{*}{ Species } & \multicolumn{2}{|l|}{$\mathrm{A}^{\mathrm{a}}$} & \multicolumn{2}{|l|}{$\mathrm{B}$} & \multicolumn{2}{|l|}{$\mathrm{C}$} & \multirow[t]{2}{*}{ Total } & \multirow[t]{2}{*}{$\%$} \\
\hline & $N^{\mathrm{b}}$ & $\%$ & $N$ & $\%$ & $N$ & $\%$ & & \\
\hline Thrips angusticeps Uzel, 1895 & 1653 & 70.5 & 1370 & 66.8 & 1213 & 66.9 & 4236 & 68.3 \\
\hline Aeolothrips intermedius Bagnall, 1934 & 326 & 13.8 & 292 & 14.3 & 321 & 17.6 & 939 & 15.1 \\
\hline Thrips tabaci Lindeman, 1889 & 312 & 13.2 & 328 & 16.0 & 236 & 13.0 & 876 & 14.1 \\
\hline Frankliniella intonsa (Trybom, 1895) & 8 & 0.3 & 17 & 0.8 & 5 & 0.3 & 30 & 0.5 \\
\hline Frankliniella tenuicornis Uzel, 1895 & 14 & 0.8 & 7 & 0.3 & 7 & 0.4 & 28 & 0.5 \\
\hline Anaphothrips obscurus (Muller, 1776) & 7 & 0.3 & 5 & 0.2 & 6 & 0.3 & 18 & 0.3 \\
\hline Haplothrips aculeatus Fabricius, 1803 & 4 & 0.2 & 3 & 0.1 & 8 & 0.4 & 15 & 0.2 \\
\hline Chirothrips manicatus Haliday, 1836 & 2 & 0.1 & 4 & 0.2 & 5 & 0.3 & 11 & 0.2 \\
\hline Thrips atratus Haliday, 1836 & 6 & 0.3 & 4 & 0.2 & 1 & 0.1 & 11 & 0.2 \\
\hline Limothrips denticornis Haliday, 1836 & 3 & 0.1 & 5 & 0.2 & 1 & 0.1 & 9 & 0.1 \\
\hline Stenothrips graminum Uzel, 1895 & 2 & 0.1 & & & 4 & 0.2 & 6 & 0.1 \\
\hline Thrips major Uzel, 1895 & 2 & 0.1 & 2 & 0.1 & & & 4 & 0.1 \\
\hline Thrips spp. & & & 3 & 0.1 & 1 & 0.1 & 4 & 0.1 \\
\hline Thrips flavus Schrank, 1776 & & & 1 & 0.1 & 2 & 0.1 & 3 & 0.1 \\
\hline Haplothrips setiger Priesner, 1921 & & & 2 & 0.1 & & & 2 & 0.1 \\
\hline Neohydatothrips gracilicornis (Williams, 1916) & 2 & 0.1 & & & & & 2 & 0.1 \\
\hline Thrips physapus Linnaeus, 1758 & & & 1 & 0.1 & 1 & 0.1 & 2 & 0.1 \\
\hline Cephalothrips monilicornis (O. M. Reuter, 1880) & & & 1 & 0.1 & 1 & 0.1 & 2 & 0.1 \\
\hline Haplothrips angusticornis Priesner, 1921 & 1 & 0.1 & & & & & 1 & 0.1 \\
\hline Haplothrips propinqus Bagnall, 1933 & & & 1 & 0.1 & & & 1 & 0.1 \\
\hline Odontothrips loti (Haliday, 1852) & & & 1 & 0.1 & & & 1 & 0.1 \\
\hline Oxythrips ajugae Uzel, 1895 & 1 & 0.1 & & & & & 1 & 0.1 \\
\hline Thrips fuscipennis Haliday, 1836 & & & 1 & 0.1 & & & 1 & 0.1 \\
\hline Total & $2343 a^{c}$ & 100 & $2048 \mathrm{a}$ & 100 & $1812 \mathrm{a}$ & 100 & 6203 & 100 \\
\hline Number of species & 15 & & 19 & & 15 & & 23 & \\
\hline
\end{tabular}

Superscript ' $a$ ' indicates type of linseed: A-linseed overproducing flavonoids, B-linseed overproducing glycoside derivatives of phenylpropanoids, $\mathrm{C}$-non-modified linseed, superscript ' $\mathrm{b}$ ' indicates number of thrips and superscript ' $c$ ' indicates significant differences in total numbers of thrips

Different small letters next to total numbers of thrips indicate significant differences between the treatments

The population of Thrips tabaci was mainly represented by females. In 2011, in each treatment sex ratio reached $100 \%$. In 2012, in samples collected from type A and type B oil flax, only single males were found. More males occurred on plots of control plants, and the sex ratio was $83.1 \%$. In 2013, again only females were identified in type $\mathrm{B}$ and type $\mathrm{C}$ combinations, while in the type A combination few males occurred. In this combination, the sex ratio reached $92 \%$. Vasiliu-Oromulu [55] from mountainous meadows, Šmatas [51], Šmatas et al. [ 52] from winter rye and winter wheat also identified mainly females of $T$. tabaci. In the Netherlands, the male/female ratio on leek was $1 / 26$ [56]. There are two reproductive modes in $T$. tabaci: thelytoky (asexual reproduction) and arrhenotoky (sexual reproduction) [24]. In thelytokous populations only females exist, and in arrhenotokous, both males and females. These two reproductive modes may coexist in populations collected in the field [38]. However, they differ ecologically and genetically, also in terms of different host preferences [33].

In the population of Aeolothrips intermedius males occurred in greater numbers in each treatment than in the two previously mentioned species. The average sex ratio of this predatory species was $70.3 \%$ and ranged from 61.5 to $77.1 \%$ (Table 5). In our trials conducted in the same location on Andean lupin, a lower mean sex ratio of $A$. intermedius was determined (45.8\%) [22]. Similarly, a lower ratio $(50 \%)$ in an alfalfa crop was reported by Barbuceanu and Vasiliu-Oromulu [2], but it was much higher in mountainous meadows: $77.5 \%$ (shaking method) and $82.3 \%$ (sweep net method) [55].

It was expected that GMO linseed plants overproducing flavonoids or glycoside derivatives of phenylpropanoids can influence the thrips sex ratio of the most numerous species. The results of the presented study do not confirm this hypothesis. 
Table 3 Species composition of thrips collected by sweep net in 2013

\begin{tabular}{|c|c|c|c|c|c|c|c|c|}
\hline \multirow[t]{2}{*}{ Species } & \multicolumn{2}{|l|}{$\mathrm{A}^{\mathrm{a}}$} & \multicolumn{2}{|l|}{ B } & \multicolumn{2}{|l|}{$\mathrm{C}$} & \multirow[t]{2}{*}{ Total } & \multirow[t]{2}{*}{$\%$} \\
\hline & $N^{\mathrm{b}}$ & $\%$ & $N$ & $\%$ & $N$ & $\%$ & & \\
\hline Thrips angusticeps Uzel, 1895 & 668 & 56.0 & 766 & 51.5 & 815 & 44.8 & 2249 & 50.0 \\
\hline Aeolothrips intermedius Bagnall, 1934 & 197 & 16.5 & 309 & 20.8 & 572 & 31.4 & 1078 & 24.0 \\
\hline Thrips tabaci Lindeman, 1889 & 226 & 18.9 & 339 & 22.7 & 342 & 18.8 & 907 & 20.2 \\
\hline Limothrips denticornis Haliday, 1836 & 37 & 3.1 & 26 & 1.7 & 20 & 1.1 & 83 & 1.8 \\
\hline Chirothrips manicatus Haliday, 1836 & 19 & 2.0 & 15 & 1.0 & 14 & 0.8 & 48 & 1.1 \\
\hline Haplothrips aculeatus Fabricius, 1803 & 12 & 1.0 & 9 & 0.6 & 6 & 0.3 & 27 & 0.6 \\
\hline Frankliniella tenuicornis Uzel, 1895 & 9 & 0.9 & 1 & 0.1 & 16 & 0.9 & 26 & 0.6 \\
\hline Anaphothrips obscurus (Muller, 1776) & 1 & 0.1 & 2 & 0.1 & 8 & 0.4 & 11 & 0.2 \\
\hline Frankliniella intonsa (Trybom, 1895) & 5 & 0.3 & 3 & 0.2 & 3 & 0.2 & 11 & 0.2 \\
\hline Limothrips cerealium Haliday, 1836 & 3 & 0.2 & 2 & 0.1 & 6 & 0.3 & 11 & 0.2 \\
\hline Stenothrips graminum Uzel, 1895 & 6 & 0.4 & 2 & 0.1 & 3 & 0.2 & 11 & 0.2 \\
\hline Thrips major Uzel, 1895 & 2 & 0.1 & 7 & 0.5 & & & 9 & 0.2 \\
\hline Chirothrips ambulans Bagnall, 1932 & & & & & 5 & 0.3 & 5 & 0.1 \\
\hline Thrips atratus Haliday, 1836 & 4 & 0.2 & & & 1 & 0.1 & 5 & 0.1 \\
\hline Haplothrips setiger Priesner, 1921 & & & 2 & 0.1 & 2 & 0.1 & 4 & 0.1 \\
\hline Thrips physapus Linnaeus, 1758 & & & & & 2 & 0.1 & 2 & 0.1 \\
\hline Aeolothrips fasciatus (Linnaeus, 1758) & & & 1 & 0.1 & & & 1 & 0.1 \\
\hline Chirothrips hamatus Trybom, 1895 & 1 & 0.1 & & & & & 1 & 0.1 \\
\hline Haplothrips alpester Priesner, 1914 & 1 & 0.1 & & & & & 1 & 0.1 \\
\hline Haplothrips sp. & & & 1 & 0.1 & & & 1 & 0.1 \\
\hline Odontothrips meliloti Priesner, 1951 & & & & & 1 & 0.1 & 1 & 0.1 \\
\hline Thrips brevicornis Priesner, 1920 & & & & & 1 & 0.1 & 1 & 0.1 \\
\hline Thrips fuscipennis Haliday, 1836 & 1 & 0.1 & & & & & 1 & 0.1 \\
\hline Thrips sp. & & & 1 & 0.1 & & & 1 & 0.1 \\
\hline Total & $1192 b^{c}$ & 100 & $1486 \mathrm{ab}$ & 100 & $1817 \mathrm{a}$ & 100 & 4495 & 100 \\
\hline Number of species & 16 & & 16 & & 17 & & 24 & \\
\hline
\end{tabular}

Superscript 'a' indicates type of linseed: A-linseed overproducing flavonoids, B-linseed overproducing glycoside derivatives of phenylpropanoids, $\mathrm{C}$-non-modified linseed, superscript ' $\mathrm{b}$ ' indicates number of thrips and superscript ' $c$ ' indicates significant differences in total numbers of thrips

Different small letters next to total numbers of thrips indicate significant differences between the treatments

\section{Seasonal changes}

The seasonal changes of thrips are presented on the basis of the results achieved by the sweep net collection in 2011 and 2013. Only in both these years differences in thrips numbers between treatments were found. On the other hand, the seasonal changes of these insects in 2012 were similar to those of 2011 and 2013. In 2011, the first single thrips were collected toward the end of May (Fig. 1a). At that time, significantly more insects were found in type A plots than in type B ones. Thrips numbers increased at the end of May and reached the maximum population in the first week of June (BBCH 63-65). Significant differences in the number of thrips at the maximum of their population were found. Significantly more insects occurred on control plants (type $\mathrm{C}$ ) than on type $\mathrm{B}$ plants. In this season, thrips were collected on oil flax plants till mid-July (BBCH 85). The second lower population peak was noted at the beginning of July (BBCH 81). In the additional two collections done in the third week of June and in the first week of July again more Thysanoptera were found on control plants than on type A and type B ones. As shown in Fig. 1b in the first three collections in 2011 (second half of May and first half of June) among the dominant species on linseed plants this season, $T$. angusticeps or T. angusticeps and $A$. intermedius were numerous. In the last three collections (second half of June and first half of July), mainly A. intermedius was identified.

In 2013, the first sweep net collection was done at the beginning of June. Plants at that time were at the BBCH stage 30-32 (Fig. 2a). The peak of the thrips population was noticed on July 18 , when plants were at $\mathrm{BBCH}$ stage 62-65. During the population peak significantly more insects were collected on type B plants than on type C ones. The second lower peak of population was observed in mid-July. During this season, thrips were collected on oil 
Table 4 Species composition of thrips collected by shaking plants in 2011-2013

\begin{tabular}{|c|c|c|c|c|c|c|c|c|}
\hline \multirow[t]{2}{*}{ Species } & \multicolumn{2}{|l|}{$\mathrm{A}^{\mathrm{a}}$} & \multicolumn{2}{|l|}{ B } & \multicolumn{2}{|l|}{$\mathrm{C}$} & \multirow[t]{2}{*}{ Total } & \multirow[t]{2}{*}{$\%$} \\
\hline & $N^{\mathrm{b}}$ & $\%$ & $N$ & $\%$ & $N$ & $\%$ & & \\
\hline \multicolumn{9}{|l|}{2011} \\
\hline Thrips tabaci Lindeman, 1889 & 5 & 50.0 & 9 & 50.0 & 7 & 58.3 & 21 & 52.5 \\
\hline Thrips angusticeps Uzel, 1895 & 3 & 30.0 & 4 & 22.2 & 3 & 25.0 & 10 & 25.0 \\
\hline Aeolothrips intermedius Bagnall, 1934 & 2 & 20.0 & 1 & 5.6 & & & 3 & 7.5 \\
\hline Frankliniella intonsa (Trybom, 1895) & & & 2 & 11.1 & 1 & 8.3 & 3 & 7.5 \\
\hline Thrips atratus Haliday, 1836 & & & 1 & 5.6 & 1 & 8.3 & 2 & 5.0 \\
\hline Limothrips denticornis Haliday, 1836 & & & 1 & 5.6 & & & 1 & 2.5 \\
\hline Total & 10 & 100 & 18 & 100 & 12 & 100 & 40 & 100 \\
\hline Number of species & 3 & & 6 & & 4 & & 6 & \\
\hline \multicolumn{9}{|l|}{2012} \\
\hline Thrips angusticeps Uzel, 1895 & 18 & 78.3 & 41 & 69.5 & 34 & 75.6 & 93 & 73.2 \\
\hline Thrips tabaci Lindeman, 1889 & 4 & 17.4 & 13 & 22.0 & 8 & 13.6 & 25 & 19.7 \\
\hline Frankliniella intonsa (Trybom, 1895) & 1 & 4.3 & 3 & 5.1 & 2 & 4.5 & 6 & 4.7 \\
\hline Aeolothrips intermedius Bagnall, 1934 & & & 2 & 3.4 & & & 2 & 1.6 \\
\hline Chirothrips manicatus Haliday, 1836 & & & & & 1 & 2.3 & 1 & 0.8 \\
\hline Total & 23 & 100 & 59 & 100 & 45 & 100 & 127 & 100 \\
\hline Number of species & 3 & & 4 & & 4 & & 5 & \\
\hline \multicolumn{9}{|l|}{2013} \\
\hline Thrips angusticeps Uzel, 1895 & 27 & 93.1 & 28 & 82.4 & 22 & 88.0 & 77 & 87.5 \\
\hline Thrips tabaci Lindeman, 1889 & 1 & 3.4 & 6 & 17.6 & 2 & 8.0 & 9 & 10.2 \\
\hline Anaphothrips obscurus (Muller, 1776) & 1 & 3.4 & & & 1 & 4.0 & 2 & 2.3 \\
\hline Total & 29 & & 34 & 100 & 25 & 100 & 88 & 100 \\
\hline Number of species & 3 & & 2 & & 3 & & 3 & \\
\hline
\end{tabular}

Superscript 'a' indicates type of linseed: A-linseed overproducing flavonoids, B-linseed overproducing glycoside derivatives of phenylpropanoids, $\mathrm{C}$-non-modified linseed and superscript ' $b$ ' indicates number of thrips

Table 5 Sex ratio index of the most numerous species of thrips collected by sweep net in 2011-2013

\begin{tabular}{|c|c|c|c|c|c|c|c|c|c|}
\hline \multirow[t]{2}{*}{ Species } & \multicolumn{3}{|l|}{$A^{a}$} & \multicolumn{3}{|l|}{ B } & \multicolumn{3}{|l|}{$\mathrm{C}$} \\
\hline & Male & Female & $\mathrm{Sr}^{\mathrm{b}}$ & Male & Female & $\mathrm{Sr}$ & Male & Female & $\mathrm{Sr}$ \\
\hline \multicolumn{10}{|l|}{2011} \\
\hline Thrips angusticeps Uzel, 1895 & 2 & 53 & 96.4 & 2 & 8 & 80.0 & 2 & 70 & 97.2 \\
\hline Thrips tabaci Lindeman, 1889 & & 30 & 100 & & 2 & 100 & & 12 & 100 \\
\hline Aeolothrips intermedius Bagnall, 1934 & 29 & 49 & 62.8 & 11 & 37 & 77.1 & 84 & 134 & 61.5 \\
\hline \multicolumn{10}{|l|}{2012} \\
\hline Thrips angusticeps Uzel, 1895 & 376 & 1269 & 77.1 & 351 & 1011 & 74.2 & 307 & 896 & 74.5 \\
\hline Thrips tabaci Lindeman, 1889 & 1 & 241 & 99.6 & 3 & 279 & 98.9 & 31 & 152 & 83.1 \\
\hline Aeolothrips intermedius Bagnall, 1934 & 44 & 103 & 70.1 & 46 & 108 & 70.1 & 51 & 133 & 72.3 \\
\hline \multicolumn{10}{|l|}{2013} \\
\hline Thrips angusticeps Uzel, 1895 & 47 & 612 & 92.9 & 65 & 692 & 91.4 & 55 & 736 & 93.0 \\
\hline Thrips tabaci Lindeman, 1889 & 18 & 207 & 92.0 & & 338 & 100 & & 336 & 100 \\
\hline Aeolothrips intermedius Bagnall, 1934 & 44 & 137 & 75.7 & 75 & 201 & 72.8 & 156 & 368 & 70.2 \\
\hline
\end{tabular}

Superscript ' $a$ ' indicates type of linseed: A-linseed overproducing flavonoids, B-linseed overproducing glycoside derivatives of phenylpropanoids, $\mathrm{C}$-non-modified linseed and superscript ' $\mathrm{b}$ ' indicates sex ratio of thrips 
Fig. 1 Seasonal dynamics of thrips collected by sweep net on different types of linseed plants in 2011. Superscript ' $a$ ' indicates type of linseed: $A-$ linseed overproducing flavonoids, $B$-linseed overproducing glycoside derivatives of phenylpropanoids, $C$-nonmodified linseed and superscript ' $b$ ' indicates significant differences in total numbers of thrips. a all the thrips. b share of three most abundant species
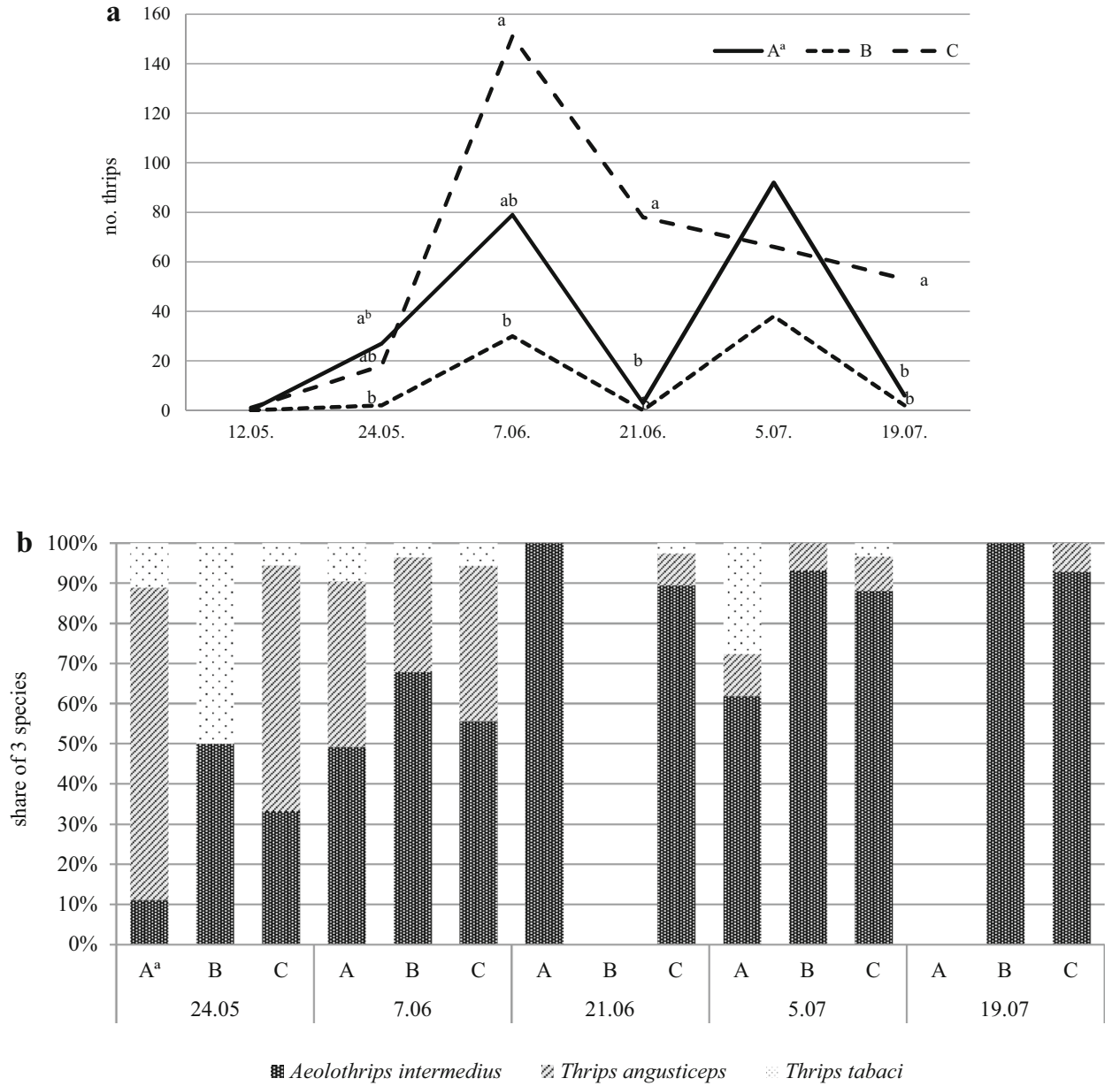

flax till the beginning of August (BBCH 89). At the beginning of July and in mid-July significantly more insects occurred on control plants than on type A and type B plants. In the collections gathered in June, among the three dominant species of Thysanoptera in 2013, $T$. angusticeps was the most abundant (Fig. 2b). In the first collection date also T. tabaci occurred in greater percentage. This species was also the most numerous in mid-July constituted almost $50 \%$ of the three dominant species. From the beginning of July, the increase in the A. intermedius percentage was observed. It was the main thrips species on linseed of each treatment at the end of July and at the beginning of August.

According to many authors, polyphagous species of thrips have two peaks of abundance in their seasonal dynamics [3, 19, 26, 30, 32]. The first, lower peak occurs in spring, and is caused mainly by wintering adult individuals which colonize crops and intensively feed as plants begin to flower. Usually at the end of May and in early June after laying eggs the population of adults decreases. The second, higher peak of abundance is usually recorded in July, and is formed by both the larvae and adults of a new generation.
In the presented trials, thrips occurring in oil flax plants, irrespective of the used genetic types of Linum usitatissimum, also had two peaks of abundance. The first, higher one occurred in the first or second ten days of June when plants were at the blooming stage. The second, lower peak of abundance was recorded in the first half of July. At this time, plants were at the ripening stage. Contrary to Franssen and Huisman [13], who observed brachypterous forms of $T$. angusticeps during the earlier stages of flax growth, only macropterous forms were noted in our studies.

There are many examples in the literature that flavonoids can reduce the growth, extend the developmental cycle, interfere with reproduction and decrease survival of many herbivorous insects belonging to different orders other than Thysanoptera $[1,9,18,23,35,37,47,53]$. Our trials showed that in 3 out of 6 sampling dates in 2011 significantly fewer thrips occurred on type B, i.e., overproducing glycoside derivatives of phenylpropanoids, than on control, non-modified plants (Fig. 1a). In the same year, in 2 out of 6 sampling dates fewer insects were also found on type A, i.e., overproducing flavonoids than on control ones. In 2013, in 2 sampling dates of 6 fewer Thysanoptera 
Fig. 2 Seasonal dynamics of thrips collected by sweep net on different types of linseed plants in 2013. Superscript ' $a$ ' indicates type of linseed: $A-$ linseed overproducing flavonoids, $B$-linseed overproducing glycoside derivatives of phenylpropanoids, $C$-nonmodified linseed and superscript ' $b$ ' indicates significant differences in total numbers of thrips. a all the thrips. b share of three most abundant species
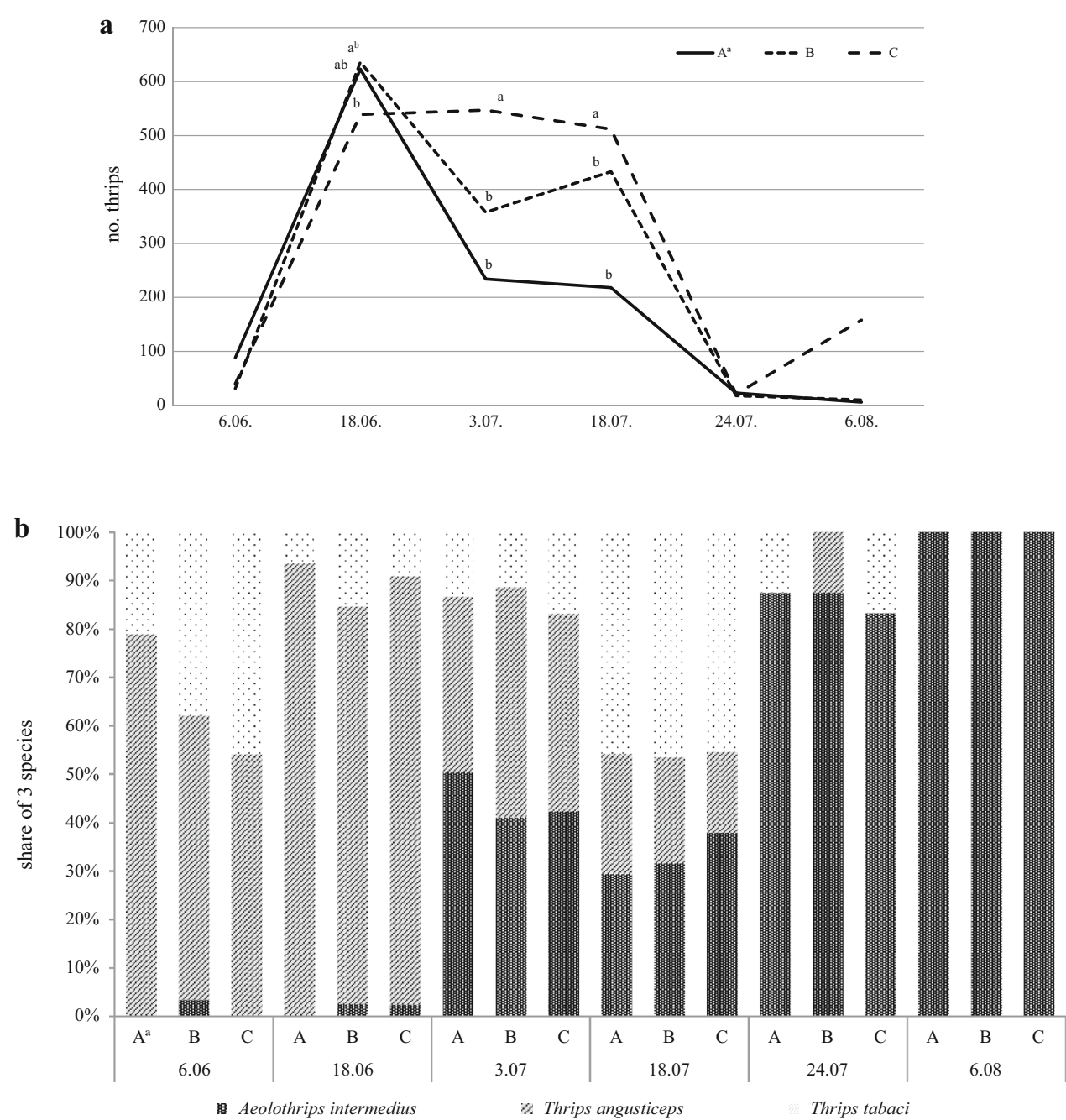

were recorded in type A oil flax and in 1 case fewer in type $\mathrm{B}$ in comparison with control plants (Fig. 2a). Taking into consideration the total number of thrips in the studied treatments, in two years significant differences were found. In 2011, fewer insects were collected on type B and in 2013 on type A in comparison with two other combinations (Tables 1,3). Additionally, on plants overproducing flavonoids fewer, i.e., 19 species, were identified versus 24 species on control ones. The results of these trials show that the presented genetically modified oil flax plants can reduce the abundance of thrips.

\section{Conclusions}

1. In the three years of the study, 33 species and 2 genera of Thysanoptera were identified on linseed plants. Irrespective of the type of oil flax used, Thrips angusticeps was the dominant species. Among phytophagous species $T$. tabaci also occurred in greater numbers. T. linarius, which is reported as a main pest of flax in Europe, was not found in our trials. The predatory Aeolothrips intermedius was among the most numerous species.

2. Thrips occurring in linseed plants, irrespective of the genetic types of Linum usitatissimum used, had two peaks of abundance. The first, and higher, occurred in the first or second ten days of June, when plants were at the blooming stage. The second, lower peak of abundance was recorded in the first half of July. At this time, plants were at the ripening stage.

3. In the most numerous species, like T. angusticeps and T. tabaci, in each treatment populations were formed mainly by females. In the population of A. intermedius males occurred in greater numbers than in the two previously mentioned species and the average sex ratio was $70.3 \%$.

4. In the three years of the study, the lower numbers of thrips occurred on the genetically modified types of flax, i.e., the ones overproducing flavonoids or 
overproducing glycoside derivatives of phenylpropanoids than on the non-transformed plants. Fewer species of Thysanoptera were identified on oil flax overproducing flavonoids in comparison with the control plants.

Acknowledgments Research was carried out with the financial support of the National Centre for Research and Development, Poland, under Project No. 12017110/2011. We are also grateful to Joanna Magiera-Dulewicz from Department of Plant Protection for her input with samples collection and laboratory work.

Open Access This article is distributed under the terms of the Creative Commons Attribution 4.0 International License (http://crea tivecommons.org/licenses/by/4.0/), which permits unrestricted use, distribution, and reproduction in any medium, provided you give appropriate credit to the original author(s) and the source, provide a link to the Creative Commons license, and indicate if changes were made.

\section{References}

1. Ateyyat, M., Abu-Romman, S., Abu-Darwish, M., \& Ghabeish, I. (2012). Impact of flavonoids against woolly apple aphid, Eriosoma lanigerum (Hausmann) and its parasitoid, Aphelinus mali (Hald.). Journal of Agricultural Science, 4(2), 227-236.

2. Barbuceanu, D., \& Vasiliu-Oromulu, L. (2013). Host associations of Thysanoptera with Medicago sativa. Romanian Journal of Biology-Zoology, 58(1), 19-27.

3. Bereś, P. K., Kucharczyk, H., \& Kucharczyk, M. (2013). Thrips abundance on sweet corn in southeastern Poland and the impact of weather conditions on their populations dynamics. Bulletin of Insectology, 66(1), 143-152.

4. Bonnemaison, L., \& Bournier, A. (1964). Les thrips du lin Thrips angusticeps Uzel et Thrips linarius Uzel (Thysanoptères). Annales des Épiphyties, 15(2), 97-169. (in French with English summary).

5. Bournier, A., Lacasa, A., \& Pivot, Y. (1978). Règime alimentaire d'un thrips prèdateur (Aeolothrips intermedius Bag.). Entomophaga, 23, 403-410. (in French with English summary).

6. Brudea, V. (1990). Research on the biology of the flax thrips (Thrips linarius Uzel) in northern Moldova. Analele Institutului de Cercetari pentru Cereale si Plante Technice Fundulea, 58, 309-316. (in Romanian with English summary).

7. Czemplik, M., Kulma, A., Bazela, K., \& Szopa, J. (2012). The biomedical potential of genetically modified flax seeds overexpressing the glucosyltransferase gene. BMC Biotechnology, 12, 251.

8. Czencz, K. (1985). Thrips pests of cultivated flax. Növényvédelem, 21(7), 293-298. (in Hungarian).

9. Diaz Napal, G. N., Defago, M. T., Valladares, G. R., \& Palacios, S. M. (2010). Response of Epilachna paenulata to two flavonoids, pinocembrin and quercetin, in a comparative study. Journal of Chemical Ecology, 36(8), 898-904.

10. Draycott, A. P. (2006). Sugar beet (p. 465). Oxford: Blackwell.

11. FAOSTAT. (2015). FAO statistical database. http://faostat3.fao. org/home/index.html\#DOWNLOAD. Accessed June 20, 2016.

12. Ferguson, A. W., Bruce, D. L., \& Wiliams, I. H. (1997). Insect injury to linseed in south-east England. Crop Protection, 16(7), 643-652.

13. Franssen, C. J. H., \& Huisman, P. (1958). The biology and control of Thrips angusticeps Uzel. Verslagen Van
Landbouwkundige Onderzoekingen, 64(10), 103. (in Dutch with English summary).

14. Franssen, C. J. H., \& Mantel, W. P. (1960). The flax thrips: Thrips lini Lad. or Thrips linarius Uzel? Entomologische Berichten, 20, 30-33.

15. Gill, H. K., Garg, H., Gill, A. K., Gillett-Kaufman, J. L., \& Nault, B. A. (2015). Onion thrips (Thysanoptera: Thripidae) biology, ecology, and management in onion production systems. Journal of Integrated Pest Management, 6(1), 1-9.

16. Heller, K. (2013). Crop management of fibre flax in Europe. FIBRA Summer School, 21-27 July 2013, Catania, Italy.

17. Heller, K., Andruszewska, A., Grabowska, L., \& Wielgusz, K. (2006). Fibre flax and hemp protection in Poland and in the world. Progress in Plant Protection/Postepy w Ochronie Roślin, 46(1), 88-98. (in Polish with English summary).

18. Hoffman-Campo, C. B., Harborne, J. B., \& McCaffery, A. R. (2001). Pre-ingestive and post-ingestive effects of soya bean extracts and rutin on Trichoplusia ni growth. Entomologia Experimentalis et Applicata, 98, 181-194.

19. Hurej, M., \& Twardowski, J. (2004). Thrips (Thysanoptera) occurring on spring triticale intercropped with yellow lupine. Acta Scientarum Polonorum, Agricultura, 3(2), 263-270. (in Polish with English summary).

20. Hurej, M., Twardowski, J., \& Chrzanowska-Drożdż, B. (2010). Thrips (Thysanoptera) occurring in ears of Triticum durum Desf. in conditions of different protection level. Acta Scientarum Polonorum, Agricultura, 9(1), 3-10.

21. Hurej, M., Kucharczyk, H., Twardowski, J., \& Kozak, M. (2014). Thrips (Thysanoptera) associated with narrow-leafed lupin (Lupinus angustifolius L., 1753) intercropped with spring triticale (X Triticosecale Wittm. ex A. Camus, 1927). Romanian Agricultural Research, 31, 337-345.

22. Hurej, M., Kucharczyk, H., Twardowski, J., \& Kotecki, A. (2015). Thrips (Thysanoptera) associated with two morphological forms of Andean lupin (Lupinus mutabilis). Biologia, 70(7), 935-942.

23. Jadhav, D. R., Mallikarjuna, N., Rathore, A., \& Pokle, D. (2012). Effect of some flavonoids on survival and development of Helicoverpa armigera (Hübner) and Spodoptera litura (Feb) (Lepidoptera: Noctuidae). Asian Journal of Agricultural Sciences, 4(4), 298-307.

24. Jenser, G., \& Szenasi, A. (2004). Review of the biology and vector capability of Thrips tabaci Lindeman (Thysanoptera: Thripidae). Acta Phytopathologica et Entomologica Hungarica, 39, 137-155.

25. Kahrer, A. (1992). Monitoring the timing of peak flight activity of Thrips tabaci in cabbage fields. IOBC/WPRS Bulletin, 17, 12-16.

26. Kobro, S., Teksdal, A. E., \& Andersen, A. (2000). Cereals as host plants for thrips (Thysanoptera) in Norway. Norwegian Journal of Entomology, 47(1), 1-6.

27. Korkina, L. G. (2007). Phenylpropanoids as naturally occurring antioxidants: From plant defense to human health. Cell and Molecular Biology, 53, 15-25.

28. Kucharczyk, H. (2010). Comparative morphology of the second larval instar of the Thrips genus species (Thysanoptera: Thripidae) occurring in Poland (p. 152). Olsztyn: Mantis.

29. Kucharczyk, H., Setniewska, M., \& Legutowska, A. (2006). Differentiation of thrips (Thysanoptera) fauna on herbal plants in Warsaw region. Progress in Plant Protection/Postepy w Ochronie Roślin, 46, 429-432. (in Polish with English summary).

30. Kucharczyk, H., Bereś, P. K., \& Dąbrowski, Z. T. (2011). The species composition and seasonal dynamice of thrips (Thysanoptera) populations on maize (Zea mays L.) in southeastern Poland. Journal of Plant Protection Research, 51(3), 210-216. 
31. Legutowska, H., \& Theunissen, J. (2003). Thrips species in leeks and their undersown intercrops. IOBC/WPRS Bulletin, 26(3), 177-182.

32. Lewis, T. (1973). Thrips. Their biology, ecology and economic importance (p. 349). London: Academic Press.

33. Li, X.-W., Fail, J., Wang, P., Feng, J.-N., \& Shelton, A. M. (2014). Performance of arrhenotokous and thelytokous Thrips tabaci (Thysanoptera: Thripidae) on onion and cabbage and its implications on evolution and pest management. Journal of Economical Entomology, 107(4), 1526-1534.

34. Liu, T. X., \& Sparks, A. N. (2003). Injury and distribution of onion thrips (Thysanoptera: Thripidae) in red cabbage heads. Southwestern Entomologist, 28, 77-79.

35. Mallikarjuna, N., Kranthi, K. R., Jadhav, D. R., Kranthi, S., \& Chandra, S. (2004). Influence of foliar chemical compounds on the development of Spodoptera litura (Fab.) in interspecific derivatives of groundnut. Journal of Applied Entomology, 128, 321-328.

36. Martens, S., \& Mithöfer, A. (2005). Flavones and flavone synthases. Phytochemistry, 66(20), 2399-2407.

37. Musayimana, T., Saxena, R. C., Kaimu, E. W., Ogol, C. P. K. O., \& Khan, Z. R. (2001). Effects of neem seed derivatives on behavioral and physiological responses of the Cosmopolites sordidus (Coleoptera: Curculionidae). Journal of Economical Entomology, 94, 449-454.

38. Nault, B. A., Shelton, A. M., Gangloff-Kaufmann, J. L., Clark, M. E., Werren, J. L., Cabrera-la Rosa, J. C., et al. (2006). Reproductive modes in onion thrips (Thysanoptera: Thripidae) populations from New York onion fields. Environmental Entomology, 35, 1264-1271.

39. Nawrocka, B. (2003). Economic importance and the control method of Thrips tabaci Lind. on onion. IOBC/WPRS Bulletin, $26,321-324$.

40. Oomah, B. D. (2001). Flaxseed as a functional food source. Journal of the Science of Food and Agriculture, 81, 889-894.

41. Pobożniak, M. (2011). The occurrence of thrips (Thysanoptera) on food legumes (Fabaceae). Journal of Plant Diseases and Protection, 118(5), 185-193.

42. Pobożniak, M., \& Wiech, K. (2005). Monitoring and occurrence of thrips (Thysanoptera) on white cabbage and white cabbage undersowing with white clover. IOBC/WPRS Bulletin, 28, 7-13.

43. Pourian, H.-R., Mirab-balou, M., Alizadeh, M., \& Orosz, S. (2009). Study on biology of onion thrips, Thrips tabaci Lindeman (Thysanoptera: Thripidae) on cucumber (var. Sultan) in laboratory conditions. Journal of Plant Protection Research, 49(4), 390-394.

44. Razi, S., Laamari, M., Ouamen, S., \& Bernard, E. C. (2013). Thysanoptera survey on Vicia faba (broad bean) in the arid Biskra region of Algeria. Agriculture and Biology Journal of North America, 4(3), 268-274.

45. Riudavets, J. (1995). Predators of Frankliniella occidentalis (Perg.) and Thrips tabaci Lind. In A. J. M. Loomans, et al., (Eds.), Biological control of thrips pests. Wageningen Agric. Univ. Papers (vol. 95(1), pp. 43-87).
46. Sakimura, K. (1963). Frankliniella fusca, an additional vector for the tomato spotted wilt virus, with notes on Thrips tabaci, another vector. Phytopathology, 53, 412-415.

47. Simmonds, M. S. J. (2003). Flavonoid-insect interactions: Recent advances in our knowledge. Phytochemistry, 64, 21-30.

48. Simmonds, M. S. J., Blaney, W. M., \& Fellows, L. E. (1990). Behavioral and electrophysiological study of antifeedant mechanisms associated with polyhydroxyalkaloids. Journal of Chemical Ecology, 16, 3167-3196.

49. Singh, K. K., Mridula, D., Rehal, J., \& Barnwal, P. (2011). Flaxseed: A potential source of food, feed and fiber. Critical Reviews in Food Science and Nutrition, 51, 210-222.

50. StatSoft. (2014). Statistica (data analysis software system), version 12 PL. http://www.statsoft.pl. Accessed June 17, 2016.

51. Šmatas, R. (2009). Species structure and sex ratio of thrips (Thysanoptera) on winter rye (Secale cereale). ZemdirbysteAgriculture, 96(4), 260-267.

52. Šmatas, R., Tamosiunas, K., \& Danyte, V. (2013). Diversity and sex ratio of thrips (Thysanoptera) species in winter wheat in Lithuania. Zemdirbyste-Agriculture, 100(3), 289-292.

53. Stamp, N. E., \& Horwath, K. L. (1992). Interactive effects of temperature and concentrations of the flavonol rutin on growth, molt and food utilization of Manduca sexta caterpillars. Entomologia Experimentalis et Applicata, 64, 35-150.

54. Treutter, D. (2006). Significance of flavonoids in plant resistance: A review. Environmental Chemistry Letters, 4, 147-157.

55. Vasiliu-Oromulu, L. (2002). The dynamics of the sex ratio index of thrips populations in mountainous meadows. In R. Marullo, L. A. Mound (Eds.), Thrips and tospoviruses: Thrips and tospoviruses: Proceedings of the 7th International Symposium on Thysanoptera, Australian National Insect Collection, Canberra. ISBN: 0-9750206-0-9.

56. Vierbergen, G., \& Ester, A. (2000). Natural enemies and sex ratio of Thrips tabaci (Thysanoptera: Thripidae), a major pest of $\mathrm{Al}$ lium porrum in the Netherlands. Mededelingen-Faculteit Landbouwkundige en Toegepaste Biologische Wetenschappen, Universiteit Gent, 65(2a), 335-342.

57. War, A. R., Paulraj, M. G., Ahmad, T., Buhroo, A. A., Hussain, B., Ignacimuthu, S., et al. (2012). Mechanisms of plant defense against insect herbivores. Plant Signal \& Behavior, 7(10), 1306-1320.

58. Wise, I. L., \& Soroka, J. J. (2003). Principal insect pests of flax. In A. D. Muir \& N. D. Westcott (Eds.), Flax the genus Linum (pp. 142-145). London: Routlege/Taylor and Francis.

59. Zawirska, I. (1960). The fauna Thysanoptera on flax. Biuletyn Instytutu Ochrony Roślin, 10, 69-75. (in Polish).

60. Zawirska, I. (1963). Contribution on the biology of Thrips linarius Uzel. Biuletyn Instytutu Ochrony Roślin, 1, 1-10. (in Polish).

61. Zuk, M., Kulma, A., Dyminska, L., Szoltysek, K., Prescha, A., Hanuza, J., et al. (2011). Flavonoid engineering of flax potentiate its biotechnological application. BMC Biotechnology, 11, 10.

62. Zuk, M., Richter, D., Matuła, J., \& Szopa, J. (2015). Linseed, the multipurpose plant. Industrial Crops and Products, 75, 165-177. 